\title{
The fungal literature-based occurrence database for southern West Siberia (Russia)
}

\author{
Nina Filippova ${ }^{\ddagger}$, Dmitry Ageev§, Sergey Bolshakovl, Evgeny A. Davydov ${ }^{\mathbb{T}, \#}$, Aleksandra Filippova", \\ Ilya Filippov $\ddagger$, Sergei Gashkov", Irina Gorbunova\#, Ludmila Kalininal, Nadezhda Kudashova", \\ Ekaterina Palomozhnykhl, Natalia Shabanova", Maria Tomoshevich\#, Olga Vayshlya", \\ Anastasia Vlasenko\#, Vyacheslav Vlasenko", Irina Vorob'eva\#, Lidia Yakovchenko\#, Elena Zvyagina" \\ ‡ Yugra State University, Khanty-Mansiysk, Russia \\ $\S$ O०० (Limited Liability Company) "SIGNATEC", Novosibirsk, Russia \\ | Komarov Botanical Institute of the Russian Academy of Sciences, Saint Petersburg, Russia \\ If Altai State University, Barnaul, Russia \\ \# Central Siberian Botanical Garden, Novosibirsk, Russia \\ Kemerovo State University, Kemerovo, Russia \\ « National Research Tomsk State University, Tomsk, Russia \\ " Lomonosov Moscow State University, Moscow, Russia
}

Corresponding author: Nina Filippova (filippova.courlee.nina@gmail.com)

Academic editor: Dmitry Schigel

Received: 20 Oct 2021 | Accepted: 06 Dec 2021 | Published: 13 Dec 2021

Citation: Filippova N, Ageev D, Bolshakov S, Davydov EA, Filippova A, Filippov I, Gashkov S, Gorbunova I, Kalinina L, Kudashova N, Palomozhnykh E, Shabanova N, Tomoshevich M, Vayshlya O, Vlasenko A, Vlasenko V, Vorob'eva I, Yakovchenko L, Zvyagina E (2021) The fungal literature-based occurrence database for southern West Siberia (Russia). Biodiversity Data Journal 9: e76789. https://doi.org/10.3897/BDJ.9.e76789

\section{Abstract}

\section{Background}

The paper presents the initiative on literature-based occurrence data mobilisation of fungi and fungi-related organisms (literature-based occurrences, Darwin Core MaterialCitation) to develop the Fungal literature-based occurrence database for the southern West Siberia (FuSWS). The initiative on mobilisation of literature-based occurrence data started in the northern part of West Siberia in 2016. The present project extends the initiative to the southern regions and includes ten administrative territories (Tyumen Region, Sverdlovsk Region, Chelyabinsk Region, Omsk Region, Kurgan Region, Tomsk Region, Novosibirsk Region, Kemerovo Region, Altai Territory and Republic of Altai). The area occupies the 
central to southern part of the West Siberian Plain and extends for about $1.5 \mathrm{~K} \mathrm{~km}$ from the west to the east from the eastern slopes of the Ural Mountains to Yenisey River and from north to south-about $1.3 \mathrm{~K} \mathrm{~km}$. The total area equals about 1.4 million $\mathrm{km}^{2}$.

The initiative is actively growing in spatial, collaboration and data accumulation terms. The working group of about 30 mycologists from eight organisations dedicated to the data mobilisation was created as part of the Siberian Mycological Society (informal organisation since 2019). They have compiled the almost complete bibliographic list of mycology-related papers for the southern West Siberia, including over 900 publications for the last two centuries (the earliest dated 1800). All literature sources were digitised and an online library was created to integrate bibliography metadata and digitised papers using Zotero bibliography manager. The analysis of published sources showed that about two-thirds of works contain occurrences of fungi for the scope of mobilisation.

At the time of the paper submission, the database had been populated with a total of about $8 \mathrm{~K}$ records from 93 sources. The dataset is uploaded to GBIF, where it is available for online search of species occurrences and/or download. The project's page with the introduction, templates, bibliography list, video-presentations and written instructions is available (in Russian) at the web site of the Siberian Mycological Society. The initiative will be continued in the following years to extract the records from all published sources.

\section{New information}

The paper presents the first project with the aim of literature-based occurrence data mobilisation of fungi and fungi-related organisms in the southern West Siberia. The full bibliography and a digital library of all regional mycological publications created for the first time includes about 900 published works. By the time of paper submission, nearly $8 \mathrm{~K}$ occurrence records were extracted from about 90 literature sources and integrated into the FuSWS database published in GBIF.

\section{Keywords}

occurrence, specimen, materialCitation, funga, fungi, Mycobiota, digitisation, biodiversity data mobilisation, GBIF

\section{Introduction}

The mycological research in the southern part of West Siberia stems from isolated studies at the end of the $19^{\text {th }}$ century, yet regular and systematic research only began in the second half of the century. Over the following decades, several dozen researchers worked in the area and a total of over 1000 scientific works were published. The history of research of particular fungal groups was earlier described in a series of publications (Milovidova 1983, Davydov and Skachko 2014, Shirjaeva 2015, Sedel'nikova 2017). Below, we 
describe the history of mycological research in the southern part of West Siberia by traditionally-studied morphological or ecological groups.

\section{Overview of the mycological research reflected in the database}

The lichen diversity in the region has been studied for more than hundred years. Irregular collections of lichens started at the end of the $19^{\text {th }}$ century by broad-scale collectors (from: Sedel'nikova 2017). This first period was summarised in a book chapter by Savich and Elenkin (1950). More systematic research of lichens started in the region in the second half of the $20^{\text {th }}$ century. In total, about 10 lichenologists worked in the area and published the results of the inventory or monitoring work. Systematic research of lichen diversity was made by Nellya V. Sedelnikova in several regions of southern West Siberia (occurrences summarised in Sedel'nikova 2017). Evgeny A. Davydov has been studying the lichen biota in Altai mountains (Davydov 2001, Davydov 2004, Davydov et al. 2007, Davydov and Printzen 2012, Davydov and Printzen 2012, Davydov 2012, Davydov et al. 2012) and Elena Y. Skachko in Altai plain (Barnaul vicinity) (Skachko 2003). Vera V. Koneva described the lichen communities and diversity in Tomsk Region (Koneva 2003). Eugene V. Barsukov studied lichen communities of pine forests in Novosibirsk Region (Barsukov 2001). In Omsk Region, lichen diversity of forest-steppe zone was studied by Natalia V. Sorokina (Sorokina 2001a, Sorokina 2001b). Ekaterina V. Romanova revealed bioindicator activity of lichens in Novosibirsk Region (Sedel'nikova and Romanova 2010). A detailed history of lichen research in Altai Territory provided in Davydov and Skachko (2014) and for West Siberia as a whole in (Sedel'nikova 2017). A number of important new records and species new for science were reported recently (Vondrák et al. 2016, Davydov and Konoreva 2017, Davydov and Yakovchenko 2017, Yakovchenko et al. 2017, Vondrák et al. 2019, Yakovchenko and Davydov 2018, Paukov et al. 2019, Yakovchenko et al. 2019, Paukov and Davydov 2020, Davydov et al. 2021).

Agaricoid basidiomycetes is a well, but unevenly, studied group in the region. Scientists performed targeted surveys on the group in Novosibirsk Region, Tomsk Region, Republic of Altai and Altai Territory. In the 1930s, the prominent mycologist of the $20^{\text {th }}$ century Rolf Singer visited the Altai Mountains, accompanied by Lubov' N. Vasiljeva. The collections made during the fieldwork were studied and cited in a number of papers, including the monumental "Das System der Agaricales III" (Singer 1943). In the 1960s, Nina V. Perova actually established the "mycological centre" in Novosibirsk which initiated the surveys of larger fungi of southern West Siberia, namely in Altai Republic, as well as Novosibirsk and Tomsk Regions with minor data from Kemerovo Region (Perova and Gorbunova 2001). In the 1990s, her successor Irina A. Gorbunova continued the work in various parts of the region, including several protected areas (Perova and Gorbunova 2007, Gorbunova et al. 2011, Gorbunova 2017, Gorbunova 2018). In the 2000s, Natalia P. Kutafieva started surveys in the Tomsk Region (Kosheleva and Kutaf'eva 2004). Later, Nadezhda N. Kudashova (Agafonova N.N.) with colleagues summarised all known data on larger fungi of the region (Kosheleva and Kutaf'eva 2004) and later added new information (Kudashova et al. 2016a, Kudashova et al. 2016b). In the borders of Kurgan, Omsk, Kemerovo and Tyumen Regions, only scattered data on agaricoid fungi can be found in several 
summarising works (Stepanova and Sirko 1977, Anonymous 1980, Mukhin 1993, Perova and Gorbunova 2001, Filippova et al. 2018). A detailed history of mycological studies in Sverdlovsk Region can be found in the summary by Olga S. Shiryaeva (Shirjaeva 2015).

Gasteroid fungi were studied by Yury A. Rebriev with co-authors (Rebriev and Gorbunova 2007, Shiryaev 2008a, Agafonova et al. 2011, Gorbunova and Rebriev 2018).

Clavarioid fungi were inventoried in different regions by Anton G. Shiryaev with colleagues (Shiryaev 2008b, Shiryaev and Gorbunova 2012, Vlasenko and Vlasenko 2017b).

The history of aphyllophoroid basidiomycetes research is described in Vlasenko (2013a). The southern West Siberia was less studied compared to the northern part, until recently. In the beginning of the $20^{\text {th }}$ century, the sporadic collection work was done by Nikolay N. Lavrov, Konstantin E. Murashkinskiy, M. K. Ziling, V. P. Dravert, V. V. Popov and others (from: Vlasenko 2013a). E. Zhukov (2002) and Zhukov (2005) were studying lignicolous basidiomycetes in Altai, Novosibirsk and Tomsk Regions in more detail at the end of the $20^{\text {th }}$ century. A relatively well-studied area by the school of aphyllophorologists is Sverdlovsk Region, importantly in mountains of the Urals (Mukhin 1993, Mukhin et al. 2003). In Altai Territory, the important inventories were made in the pine forests of foreststeppe zone (Vlasenko 2010, Vlasenko 2013a), in plantations and native forests of Novosibirsk (Vlasenko 2013b, Vlasenko 2014) and in different nature protected areas (Vlasenko and Vlasenko 2015, Vlasenko and Vlasenko 2017a, Vlasenko et al. 2019). In Tomsk Region, the first checklist of aphyllophoroid fungi was published in Agafonova et al. (2007b). The biological activity of agaricoid and aphyllophoroid basidiomycetes has been studied in Novosibirsk in different research projects, mentioning a few in the following references (Ibragimova et al. 2013, Troshkova et al. 2013, Protsenko et al. 2019).

Study of fungal plant pathogens in West Siberia started at the beginning of the $20^{\text {th }}$ century. Several regional checklists were created back then (Lavrov 1926, Murashkinskiy and Ziling 1928, Lavrov 1937, Lavrov 1938, Lavrov 1951a, Lavrov 1951b) and several monographs on special groups were published (Vasil'evskiy and Karakulin 1937, Transhel' 1939, Vasil'evskiy and Karakulin 1950). Further study of fungal plant pathogens in West Siberia resumed only in the $60-70$ s of the $20^{\text {th }}$ century. Plant pathogens in Tomsk City and Tomsk Region were studied by several authors (Milovidova and Melekhina 1971, Milovidova and Melekhina 1972, Sokolovskaya and Golovina 1973, Milovidova 1983). Fungal plant pathogens of woody plants in Novosibirsk were studied by Maria V. Nozdrenko (Nozdrenko 1960, Anonymous 1961, Nozdrenko 1964, Nozdrenko 1965, Anonymous 1974) and Ateo M. Zhukov (Zhukov 1978, Zhukov 1979). More recently, the diversity of fungal plant pathogens was advanced by Irina G. Vorobieva and Maria A. Tomoshevich (Tomoshevich and Vorob'eva 2005, Tomoshevich and Vorob'eva 2010, Tomoshevich and Banaev 2011, Vorob'eva et al. 2011, Tomoshevich 2012, Tomoshevich et al. 2013, Tomoshevich and Banaev 2013, Toropova et al. 2013, Tomoshevich and Banaev 2017, Vorob'eva and Tomoshevich 2017, Vorob'eva et al. 2018, Tomoshevich 2020, Tomoshevich and Vorob'eva 2020, Vorob'eva and Tomoshevich 2021, mentioning the most important works) and by Svetlana N. Nikitina, Elena Yu. Toropova (Nikitina 2008a, Nikitina 
2008b, Toropova et al. 2013, Toropova et al. 2019, Toropova et al. 2021). A few publications were dedicated to the soil communities of micromycetes in Altai Territory, with one example given by Bilanenko and Georgieva (2005).

The history of myxomycetes research in West Siberia was presented in a paper (Vlasenko 2008). The first inventory of this group in Tomsk Region was made by Nikolay N. Lavrov (Lavrov 1927, Lavrov 1931). Recently, the systematic research of different ecological groups of myxomycetes in different regions was advanced by Anastasia V. Vlasenko with co-authors (Vlasenko 2011, Vlasenko and Novozhilov 2011, Vlasenko 2013, Vlasenko 2020, amongst others).

The description of the history of research was not intended to be complete and only describes the main fields of research of fungal diversity in the region and lists the key researchers and works. For a full mycological bibliography for the southern West Siberia, the reader is invited to read Suppl. material 1. This list is to be updated in the future and the latest version can be found in the working group' web page. For the history of mycological research in northern West Siberia, please refer to Filippova et al. (2020).

\section{Project description}

Title: The data mobilisation working group of the Siberian Mycological Society.

Personnel: The working group of about 30 mycologists from eight organisations dedicated to the fungal literature-based records mobilisation initiative was created as part of the Siberian Mycological Society (informal organisation since 2019).

\section{Sampling methods}

Study extent: The project was aimed at mobilisation of species records accumulated in the course of previous mycological studies and published in peer-reviewed scientific literature from the beginning of research up to date (Filippova et al. 2021). The geography extended throughout the southern part of West Siberia, in the administrative borders of ten regions. About 900 publications were compiled in a bibliography and a digital library and the species occurrence records were extracted from about 90 selected works by the time of paper submission. The initiative will be continued in the following years to extract the records from all published sources.

Step description: The following protocol was used to standardise and improve the mobilisation workflow:

1. The bibliography was compiled using Zotero bibliographic manager. Only published works (peer-reviewed papers, conference proceedings, PhD theses, monographs or book chapters) were selected. If possible, the sources were scanned and added to the library as PDF files. 
2. The template of the FuSWS database was made with Google Sheets and simple Microsoft Excel templates. The Darwin Core standard was applied to the database field structure to accommodate the relevant information extracted from the publications. In total, 31 fields (see detailed description in Data resources) were selected to describe the literature-based occurrence data in the needed detail.

3. From the available publications related to the region, the only works with species occurrence reports were selected for the databasing purpose. The main source of occurrences were annotated species lists with exact localities of the records. However, different sorts of other species citations were also included, provided that they had the connection to any geography and could be georeferenced at least to the regional level.

4. Most of the occurrences were georeferenced, either from the coordinates provided in the paper or from the verbatim description of the field work locality. The georeferencing of the verbatim descriptions was made using Yandex or Google map services. Depending on the quality of georeference provided in publications, the coordinate uncertainty was estimated as follows: 1) the coordinate of a fruiting structure or a plot provided in the publication gives the uncertainty about 3-30 m; 2) the coordinate of the field work locality provided in publication gives the uncertainty between $500 \mathrm{~m}$ to $5 \mathrm{~km}$; 3) the report of the species presence in a particular region gives the centroid of the area with the uncertainty radius to include its borders.

5. The locality names were reserved in the field «verbatimLocality» for accuracy.

6. When possible, the "eventDate» was extracted from the annotation data. Whenever this information was absent, the date of the publication was used instead, with the remarks in the "verbatimEventDate» field about the origin of the date.

7. The ecological features, habitat or relief were written in the «habitat» field and reserved in Russian.

8. The substrate is important feature of fungal occurrences and was extracted in the «fieldNotes» field.

9. Other annotation records, including the abundance, fruiting season and others, were accommodated in the «occurrenceRemarks» field.

10. The original scientific names reported in publications were filled in the «verbatimScientificName» field and reserved in the original database. This field was used to create the "ScientificName» field after spelling errors correction using the GBIF Species Matching tool. This tool was also used to create the additional fields of taxonomic hierarchy from species to kingdom, to fill in the "taxonRank» field and to synonymise according to the GBIF Backbone Taxonomy. 
11. To track the digitisation process, a metadata worksheet was maintained. Each bibliographic record had a series of fields to describe the digitisation process and its results: the total number of extracted occurrence records, general description of the occurrence quality, presence of the observation date, details of georeferencing and the name of a person responsible for the digitisation.

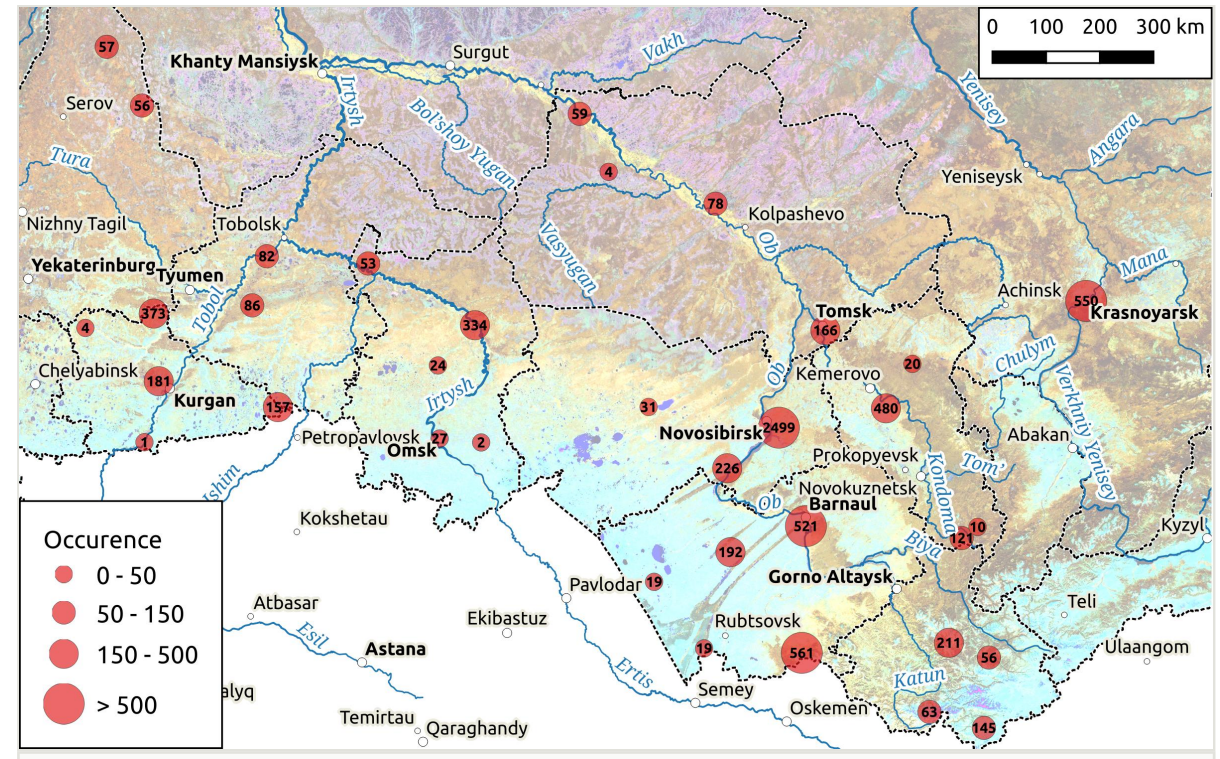

Figure 1. doi

The distribution of the occurrence records from the FuSWS on Landsat satellite image of the area. The clustering of points was made within a radius of $100 \mathrm{~km}$; the scale breaks were selected manually after plotting the frequency distribution histogram.

\section{Geographic coverage}

Description: The dataset is limited by the administrative borders of ten regions (Tyumen Region, Sverdlovsk Region, Chelyabinsk Region, Kurgan Region, Omsk Region, Tomsk Region, Novosibirsk Region, Kemerovo Region, Altai Territory and Republic of Altai).

The region occupies the central to southern part of the West Siberian Plain. The area extends for about $1.5 \mathrm{~K} \mathrm{~km}$ from the west to the east from the eastern slopes of the Ural Mountains to Yenisey River and from north to south - about $1.3 \mathrm{~K} \mathrm{~km}$. The total area equals about $1.4 \mathrm{~m} \mathrm{~km}^{2}$.

The area is very diverse in biogeographical terms, including several vegetation zones from steppe to taiga forest and mountain ecosystems. The relief in the central part is mainly a plain, but the south-eastern part of the area is occupied by several mountain systems of Altai, Salair, Kuznetsk Alatau and Gornaya Shoriya. The western part of West Siberia is bordered by the Ural Mountains. 
Most administrative divisions were covered by mycological research, but the intensity of the research varies (Fig. 1). Up to $85 \%$ of all records in the database currently made from five regions (Novosibirsk Region - 35\%, Tomsk Region - 16\%, Republic of Altai - 15\%, Altai Territory - $11 \%$ and Kemerovo Region - $11 \%$ of total occurrences). Other regions are less covered in the database and the subject of future work.

Coordinates: 49.309 and 60.907 Latitude; 61.518 and 95.4909 Longitude.

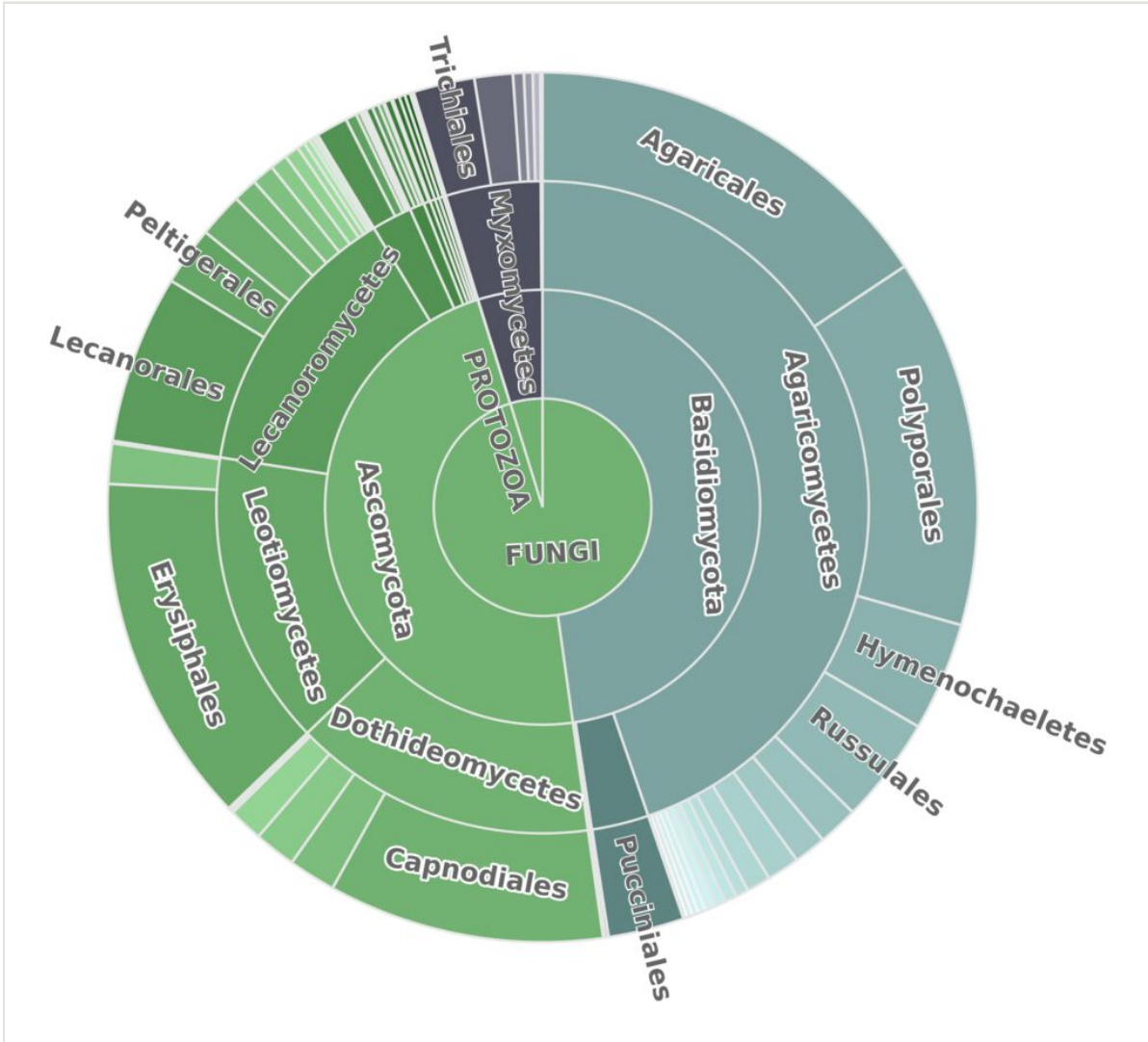

Figure 2. doi

Taxonomic distribution of occurrences in the fungal literature-based occurrence database for the southern West Siberia.

\section{Taxonomic coverage}

Description: According to the database summary report by the time of paper submission, there are occurrences of about 2200 species mobilised in the FuSWS database, which represent 800 genera, 230 families, 80 orders, 19 classes, five phyla and three kingdoms (Fungi, Protozoa, Chromista) (Fig. 2). The richest classes by number of occurrences are Agaricomycetes (44\%), Dothideomycetes (15\%), Leotiomycetes (15\%) and 
Lecanoromycetes (14\%). The richest ten families by number of occurrences are Erysiphaceae (13\%), Polyporaceae (6\%), Capnodiaceae (5\%), Mycosphaerellaceae (5\%), Meruliaceae (3\%), Fomitopsidaceae (3\%), Hymenochaetaceae (2\%), Parmeliaceae $(2 \%)$, Agaricaceae $(2 \%)$ and Venturiaceae ( $2 \%$ of all occurrences).

\section{Temporal coverage}

Data range: 1925-1-01 - 2019-1-01.

Notes: About 90 publications for the last century.

\section{Usage licence}

Usage licence: Creative Commons Public Domain Waiver (CC-Zero)

IP rights notes: This work is licensed under a Creative Commons Attribution (CC-BY) 4.0 License.

\section{Data resources}

Data package title: The Fungal Literature-based Occurrence Database for the southern West Siberia (Russia).

Resource link: https://www.gbif.org/dataset/dd7d031f-b18f-4631-929a-049fcf00ac8f

Alternative identifiers: http://ipt.ugrasu.ru:8080/ipt/resource?r=funsws

Number of data sets: 1

Data set name: The Fungal Literature-based Occurrence Database for the southern West Siberia (Russia).

Data format: Darwin Core

Description: The dataset includes a table in Darwin Core format with 31 original fields and about $8 \mathrm{~K}$ records.

\begin{tabular}{|l|l|}
\hline Column label & Column description \\
\hline occurrencelD & $\begin{array}{l}\text { https://dwc.tdwg.org/terms/\#dwc:occurrencelD; an identifier of a particular } \\
\text { occurrence, unique within this dataset. We used simple 5-digit incremental number } \\
\text { format. }\end{array}$ \\
\hline basisOfRecord & $\begin{array}{l}\text { https://dwc.tdwg.org/terms/\#dwc:basisOfRecord; according to DwC } \\
\text { recommendation, all literature-based records published to GBIF should have a } \\
\text { value "MaterialCitation" (currently unavailable in IPT, but we will change it to this } \\
\text { value in the future). }\end{array}$ \\
\hline
\end{tabular}




\begin{tabular}{|c|c|}
\hline bibliographicCitation & $\begin{array}{l}\text { https://dwc.tdwg.org/terms/\#dcterms:bibliographicCitation; the bibliographic citation } \\
\text { of a publication from which the occurrence was extracted, Elsevier - Harvard (with } \\
\text { titles). }\end{array}$ \\
\hline catalogNumber & $\begin{array}{l}\text { https://dwc.tdwg.org/terms/\#dwc:catalogNumber; the collection number or field } \\
\text { number of the specimen, if provided in annotation (for example LE } 255111 \text { - } \\
\text { specimen stored in Komarov Botanical Institude RAS). }\end{array}$ \\
\hline coordinateUncertaintylnMetres & $\begin{array}{l}\text { https://dwc.tdwg.org/terms/\#dwc:coordinateUncertaintylnMeters; see "Sampling } \\
\text { methods" for the description of the uncertainty calculation protocol. }\end{array}$ \\
\hline countryCode & $\begin{array}{l}\text { https://dwc.tdwg.org/terms/\#dwc:countryCode; the standard code for the country in } \\
\text { which the locality occurs (RU). }\end{array}$ \\
\hline county & $\begin{array}{l}\text { https://dwc.tdwg.org/terms/\#dwc:county; the full, unabbreviated name of the next } \\
\text { smaller administrative region than stateProvince (район). }\end{array}$ \\
\hline decimalLatitude & $\begin{array}{l}\text { https://dwc.tdwg.org/terms/\#dwc:decimalLatitude; the geographic latitude provided } \\
\text { in publication or determined from the provided geographic description; see } \\
\text { "Sampling methods" for georeferencing details. }\end{array}$ \\
\hline decimalLongitude & $\begin{array}{l}\text { https://dwc.tdwg.org/terms/\#dwc:verbatimLongitude; the geographic longitude } \\
\text { provided in the publication or determined from the provided geographic } \\
\text { description; see "Sampling methods" for georeferencing details. }\end{array}$ \\
\hline eventDate & $\begin{array}{l}\text { https://dwc.tdwg.org/terms/\#dwc:eventDate; the full date of the observation event if } \\
\text { provided in annotation or the year of publication itself, if absent in annotation of the } \\
\text { record. In case the year of publication added, a corresponding remark was added } \\
\text { in eventRemarks. }\end{array}$ \\
\hline fieldNotes & https://dwc.tdwg.org/terms/\#dwc:fieldNotes; the description of substrate. \\
\hline geodeticDatum & $\begin{array}{l}\text { https://dwc.tdwg.org/terms/\#dwc:geodeticDatum; the geodetic datum upon which } \\
\text { the geographic coordinates are given. }\end{array}$ \\
\hline georeferencedBy & $\begin{array}{l}\text { https://dwc.tdwg.org/terms/\#dwc:georeferencedBy; a person who determined the } \\
\text { georeference. }\end{array}$ \\
\hline georeferenceProtocol & $\begin{array}{l}\text { https://dwc.tdwg.org/terms/\#dwc:georeferenceProtocol; see "Sampling methods" } \\
\text { for georeferencing details. }\end{array}$ \\
\hline georeferenceSources & $\begin{array}{l}\text { https://dwc.tdwg.org/terms/\#dwc:georeferenceSources; the resource used to } \\
\text { georeference the locality. }\end{array}$ \\
\hline habitat & $\begin{array}{l}\text { https://dwc.tdwg.org/terms/\#dwc:habitat; the description of habitat, including } \\
\text { vegetation or relief. }\end{array}$ \\
\hline identifiedBy & https://dwc.tdwg.org/terms/\#dwc:identifiedBy; a person who identified the taxon. \\
\hline kingdom & $\begin{array}{l}\text { https://dwc.tdwg.org/terms/\#dwc:kingdom; the full scientific name of the kingdom in } \\
\text { which the taxon is classified. }\end{array}$ \\
\hline locality & $\begin{array}{l}\text { https://dwc.tdwg.org/terms/\#dwc:locality; the original locality description of the } \\
\text { collection place below county level, in English. }\end{array}$ \\
\hline
\end{tabular}




\begin{tabular}{|c|c|}
\hline occurrenceRemarks & $\begin{array}{l}\text { https://dwc.tdwg.org/terms/\#dwc:occurrenceRemarks; other annotations to the } \\
\text { record, including abundance, phenology etc. }\end{array}$ \\
\hline recordedBy & $\begin{array}{l}\text { https://dwc.tdwg.org/terms/\#dwc:recordedBy; a person responsible for the original } \\
\text { occurrence record, if present in annotation. }\end{array}$ \\
\hline scientificName & $\begin{array}{l}\text { https://dwc.tdwg.org/terms/\#dwc:scientificName; the original names as provided in } \\
\text { publication, but corrected for spelling mistakes using GBIF Species Matching tool. }\end{array}$ \\
\hline stateProvince & $\begin{array}{l}\text { https://dwc.tdwg.org/terms/\#dwc:stateProvince; the name of the next smaller } \\
\text { administrative region than country (область, край, республика). }\end{array}$ \\
\hline taxonRank & $\begin{array}{l}\text { https://dwc.tdwg.org/terms/\#dwc:taxonRank; the taxonomic rank of the most } \\
\text { specific name in the scientificName as it appears in the original publication. }\end{array}$ \\
\hline verbatimElevation & $\begin{array}{l}\text { https://dwc.tdwg.org/terms/\#dwc:verbatimElevation; the original description of the } \\
\text { elevation. }\end{array}$ \\
\hline eventRemarks & $\begin{array}{l}\text { https://dwc.tdwg.org/terms/\#dwc:eventRemarks; information whether the } \\
\text { eventDate was extracted from annotation or from a year of publication. }\end{array}$ \\
\hline verbatimLocality & $\begin{array}{l}\text { https://dwc.tdwg.org/terms/\#dwc:verbatimLocality; the original locality description } \\
\text { of the collection place below county level, reserved in original language. }\end{array}$ \\
\hline verbatimLatitude & $\begin{array}{l}\text { https://dwc.tdwg.org/terms/\#dwc:verbatimLatitude; the original latitude format as it } \\
\text { was provided in a publication. }\end{array}$ \\
\hline verbatimLongitude & $\begin{array}{l}\text { https://dwc.tdwg.org/terms/\#dwc:verbatimLongitude; the original longitude format } \\
\text { as it was provided in a publication. }\end{array}$ \\
\hline verbatimEventDate & $\begin{array}{l}\text { https://dwc.tdwg.org/terms/\#dwc:verbatimEventDate; the original representation of } \\
\text { the date as it was provided in a publication. }\end{array}$ \\
\hline language & $\begin{array}{l}\text { https://dwc.tdwg.org/terms/\#dcterms:language; a language of the dataset, which is } \\
\text { Russian for some of the fields (bibliographicReference, verbatimLocality, } \\
\text { occurrenceRemarks, habitat) and English for other fields. }\end{array}$ \\
\hline
\end{tabular}

\section{Acknowledgements}

The research was partially funded by the grant of the Tyumen Region Government in accordance with the Program of the West Siberian Interregional Scientific and Educational Center, National Project "Nauka"; and a grant for organisation of New Young Researcher Laboratories as part of the implementation of the National Project "Science and Universities"; Elena A. Zvyagina's work was supported by a grant from the Russian Foundation for Basic Research (RFBR) 20-04-00349; Maria A. Tomoshevich and Irina G. Vorob'eva were funded by budgetary project No. AAAA-A21-121011290027-6 of the Central Siberian Botanical Garden of the Siberian Branch of the Russian Academy of Sciences (CSBG SB RAS), Novosibirsk, Russia. 


\section{Author contributions}

All authors participated in compilation of bibliography and extraction of the species occurrences included in the database and participated in the revision of the paper. Nina Filippova was an initiator of the digitisation initiative and responsible for data integration and publishing in GBIF. Sergei Bolshakov made the major data cleaning work with the database. Sergei Bolshakov and Dmitry Ageev compiled the bibliography in Zotero. Ilya Filippov prepared the distribution map.

\section{References}

- $\quad$ Agafonova NN, Kryuchkova OE, Kutaf'eva NP, Gashkov SI (2007) The macromycetes of Tomsk Region (West Siberia). 2. Aphyllophoraceous fungi [Макромицеты Томской области (Западная Сибирь). 2. Афиллофоровые грибы]. Novosti Sistematiki Nizshikh Rasteniy 41: 92-101. [In Russian]. https://doi.org/10.31111/nsnr/2007.41.92

- $\quad$ Agafonova NN, Rebriev YA, Gashkov SI (2011) Gasteroid basidiomycetes of the Tomsk region [Гастероидные базидиомицеты Томской области]. Mycology and Phytopathology 45 (3): 221-227. [In Russian]. URL: https://www.elibrary.ru/item.asp? id $=16399058$

- $\quad$ Barsukov EV (2001) Lichen flora of the Priobsky pine forest (Novosibirsk region) [Лихенофрлора Приобского ленточного бора (Новосибирская область)]. Sibirskij Ekologicheskij Zhurnal 8: 507-512. [In Russian].

- Bilanenko EN, Georgieva ML (2005) Micromycetes in solonchaks of south Siberia (Kulunda steppe) [Микромицеты солончаков Южной Сибири (Кулундинская степь)]. Mycology and Phytopathology 39 (4): 6-12. [In Russian]. URL: https://elibrary.ru/ item.asp?id=9155944

- Davydov E, Printzen C (2012) Rare and noteworthy boreal lichens from the Altai Mountains (South Siberia, Russia). The Bryologist 115 (1): 61-73. https://doi.org/ 10.1639/0007-2745.115.1.61

- Davydov E, Yakovchenko L (2017) Rhizocarpon smaragdulum, a new monosporic yellow-thalline species and some additional species of the genus Rhizocarpon from the Altai Mountains (Siberia). The Lichenologist 49 (5): 457-466. https://doi.org/10.1017/ $\underline{\text { s0024282917000469 }}$

- $\quad$ Davydov E, Yakovchenko L, Hollinger J, Bungartz F, Parrinello C, Printzen C (2021) The new genus Pulvinora (Lecanoraceae) for species of the 'Lecanora pringlei' group, including the new species Pulvinora stereothallina. The Bryologist 124 (2).

https://doi.org/10.1639/0007-2745-124.2.242

- Davydov EA (2001) Catalogus annotatus lichenum montum Altai occidentalis (Rossia) [Аннотированный список лишайников западной части Алтая (Россия)]. Novosti Sistematiki Nizshikh Rastenii 35: 140-161. [In Russian].

- Davydov EA (2004) Additions to the lichen biota of the Altai Mountains I. [Дополнения к видовому составу лишайников Алтайской горной страны. I]. Turczaninowia 7 (4): 47-59. URL: http://old.ssbg.asu.ru/turcz/turcz404-47-59.pdf

- Davydov EA, Titov AN, Zamora SP (2007) Additions to the lichen biota of the Altai Mountains II [Дополнения к видовому составу лишайников Алтайской горной 
страны. II]. Turczaninowia 10 (1): 60-67. URL: http://old.ssbg.asu.ru/turcz/ turcz107-60-67.pdf

- Davydov EA (2012) Lichens of the Tigirek Nature Reserve (annotated species list) [Лишайники Тигирекского заповедника (аннотированный список видов)]. Trudy Tigirekskogo Zapovednika 4: 69-85. [In Russian].

- Davydov EA, Printzen C (2012) Additions to the lichen biota of the Altai Mountains (Siberia). III. [Дополнения к видовому составу лишайников Алтайской горной страны. III]. Turczaninowia 15 (1): 85-91. URL: http://old.ssbg.asu.ru/turcz/ turcz $15 \quad 1$ 8 $85-91$.pdf

- Davydov EA, Konoreva LA, Zhdanov IS, Dobrysh AA. (2012) Additions to the lichen biota of Altai mountains. IV. [Дополнения к видовому составу лишайников Алтайской горной страны. IV]. Turczaninowia 15 (3): 23-36. URL: http://old.ssbg.asu.ru/turcz/ turcz $15 \quad 3 \quad 23-36 . p d f$

- Davydov EA, Skachko EY (2014) History and results of study of lichens in Altay region [История и итоги изучения флоры лишайников Алтайского края]. Vestnik Altayskoy Nauki 1: 208-213. [In Russian]. URL: https://elibrary.ru/item.asp?id=21778191

- Davydov EA, Konoreva LA (2017) New data on lichens from Salair province in Altaisky krai (Siberia, Russia) [Новые данные о лишайниках Салаирского ботаникогеографического района в Алтайском краe]. Turczaninowia 20 (4): 185-197. https://doi.org/10.14258/turczaninowia.20.4.17

- Filippova AV, Kashina AY, Snigirev DY (2018) Basidiomycetes of urban and suburban plantings of the city of Kemerovo [Базидиальные грибы городских и пригородных насаждений города Кемерово]. Materialy Vserossiyskoy Konferentsii s Mezhdunarodnym Uchastiem «Mikologiya i Al'gologiya v Rossii. XX-XXI vek: Smena Paradigm»232-233. [In Russian].

- Filippova N, Arefyev S, Zvyagina E, Kapitonov V, Makarova T, Mukhin V, Sedelnikova N, Stavishenko I, Shiryaev A, Tolpysheva T, Ryabitseva N, Paukov A (2020) Fungal literature records database of the Northern West Siberia (Russia). Biodiversity Data Journal 8 https://doi.org/10.3897/BDJ.8.e52963

- Filippova N, Ageev D, Bolshakov S, Vayshlya O, Vlasenko A, Vlasenko V, Gashkov S, Gorbunova I, Davydov E, Zvyagina E, Kudashova N, Tomoshevich M, Filippova A, Shabanova N, Yakovchenko L (2021) The fungal literature-based occurrence database for the Southern West Siberia (Russia). Version 1.8. Yugra State University Biological Collection (YSU BC). Occurrence dataset https://doi.org/10.15468/eqx72v

- Gorbunova IA, Vlasenko VA, Chubarova YA (2011) Macromycetes of Tigiretsky Nature Reserve (annotated species list) [Макромицеты Тигирекского заповедника (аннотированный список видов)]. Biota Tigirekskogo zapovednika. Trudy Tigirekskogo zapovednika. 4: 57-71. [In Russian].

- Gorbunova IA (2017) New data on Agaricoid fungi of the Katunsky State Nature Reserve and rare fungi of the Republic of Altay (Russia) [Новые сведения об агарикоидных грибах Катунского заповедника и редких грибах Республики Алтай (Россия)]. Nature Conservation Research 2: 43-55. [In Russian]. https://doi.org/ 10.24189/ncr.2017.032

- $\quad$ Gorbunova IA (2018) New information about agaricoid basidiomycetes of the Tigirek State Nature Reserve (Altai territory) [Новые сведения об агарикоидных базидиомицетах заповедника «Тигирекский» (Алтайский край)]. Turczaninowia 21 (2): 160-171. [In Russian]. https://doi.org/10.14258/turczaninowia.21.2.16 
- Gorbunova IA, Rebriev YA (2018) New information about gasteroid basidiomycetes of the Tigirek State Nature Reserve (Altai territory) [Новые сведения о гастероидных и агарикоидных базидиомицетах Тигирекского заповедника]. Turczaninowia 21: 24-30. [In Russian]. https://doi.org/10.14258/turczaninowia.21.1.3

- Ibragimova ZB, Mazurkova NA, Makarevich EV, Filippova El, Troshkova GP, Kostina NE, Protsenko MA, Skarnovich MA, Shishkina LN, Gorbunova IA (2013) Antiviral activity of aqueous and ethanol fungal extracts against DNA-containing viruses [Противовирусная активность водных и этанольных грибных экстрактов в отношении ДНК-содержащих вирусов]. Sovremennye Naukoemkie Tekhnologii 4: 112. [In Russian]. URL: https://top-technologies.ru/ru/article/view?id=31628

- Koneva VV (2003) Lichens of forests and bogs of the southeastern Tomsk region [Лишайники лесных и болотных фитоценозов юго-востока Томской области]. Sibirskiy Ekologicheskiy Zhurnal 10 (4): 523-528. [In Russian]. URL: https://elibrary.ru/ item.asp?id=17641834

- $\quad$ Kosheleva AP, Kutaf'eva HP (2004) Biota of macromycetes in the region between rivers Ob and Tom (Tomsk region, West Siberia) [Биота макромицетов между речья Оби и Томи (Томская область, Западная Сибирь)]. Novosti Sistematiki Nizshikh Rastenii 37: 106-115. [In Russian]. URL: https://www.elibrary.ru/item.asp?id=18263152

- Kudashova NN, Gashkov SI, Vayshlya OB (2016a) Additions to the list of macromycetes of Tomsk region [Дополнительные данные к списку макромицетов Томской области]. Sistematicheskie Zametki Po Materialam Gerbariya im. P.N. Krylova Tomskogo Gosudarstvennogo Universiteta 114: 49-60. [In Russian]. https://doi.org/ 10.17223/20764103.114.6

- $\quad$ Kudashova NN, Gashkov SI, Vayshlya OB (2016b) Rare and protected species of fungi of Tomsk Oblast [Редкие и охраняемые виды грибов Томской области]. Vestnik Tomskogo Gosudarstvennogo Universiteta. Biologiya 4: 79-109. [In Russian]. https://doi.org/10.17223/19988591/36/6

- $\quad$ Lavrov NN (1926) Mycoflora of the lower reaches of the Yenisei River and the islands of the Yenisei Gulf [Материалы к микофрлоре низовьев реки Енисея и островов Енисейского залива]. Izvestiya Tomskogo Gosudarstvennogo Universiteta 77: 158-177. [In Russian].

- Lavrov NN (1927) Materials for the study of Siberian Myxomycetes: 1. Vicinity of the city of Tomsk [Материалы для фрлоры слизевиков Сибири: 1. Слизевики окрестностей гор. Томска]. Izvestiya Tomskogo Otdeleniya Russkogo Botanicheskogo Obshchestva 2: 10-21. [In Russian].

- Lavrov NN (1931) Myxomycetes of the Northern and Central Altay [Слизевики Северного и Центрального Алтая]. Izvestiya Tomskogo Otdeleniya Russkogo Botanicheskogo Obshchestva 3[In Russian].

- Lavrov NN (1937) Fungi and myxomycetes of Siberia and nearby regions of Europa, Asia and America. Vol. 1 [Флора грибов и слизевиков Сибири и смежных областей Европы, Азии и Америки. Вып. 1]. Trudy Tomskogo Gosudarstvennogo Universiteta Imeni V. V. Kuybysheva 104 (3): 12-59. [In Russian].

- Lavrov NN (1938) Fungi and myxomycetes of Siberia and nearby regions of Europa, Asia and America. Vol. 2 [Флора грибов и слизевиков Сибири и смежных областей Европы, Азии и Америки. Вып. 2]. Trudy Biologicheskogo Nauchno-Issledovatel'skogo Instituta III: 1-132. [In Russian]. 
- Lavrov NN (1951a) Fungi and myxomycetes of Siberia and nearby regions of Europa, Asia and America. Vol. 4. Mycopathogens of cereals [Флора грибов и слизевиков Сибири и смежных областей Европы, Азии и Америки. Вып. 4. Микофлора хлебных злаков]. Trudy Tomskogo Gosudarstvennogo Universiteta Imeny V. V. Kuybysheva 110: 1-311. [In Russian].

- Lavrov NN (1951b) Fungi and myxomycetes of Siberia and nearby regions of Europa, Asia and America. Vol. 5. Mycopathogens of Siberian grasses [Флора грибов и слизевиков Сибири. Вып. 5. Очерк микофлоры злаков Сибири]. Trudy Tomskogo Gosudarstvennogo Universiteta Imeny V. V. Kuybysheva 113: 1-104. [In Russian].

- Milovidova LS, Melekhina EE (1971) The species diversity of fungi on some trees and shrubs of the Tomsk town [Видовой состав грибов на некоторых деревьях и кустарниках, произрастающих в Томске]. Byulletel' Sibirskogo Botanicheskogo Sada 8: 90. [In Russian].

- $\quad$ Milovidova LS, Melekhina EE (1972) Phytopathogenic fungi in parks in the city of Tomsk [Вредные грибы зеленых насаждений Томска]. Vodorosli i Griby Sibiri i Dal'nego Vostoka 2 (4): 163-165. [In Russian].

- Milovidova LS (1983) Mycological and phytopathological research in Siberia [Микологические и фитопатологические исследования в Сибири]. Mycology and Phytopathology 17: 7-10. [In Russian].

- Mukhin VA (1993) Boita of lignicolous basidiomycetes of West Siberian plain [Биота ксилотрофных базидиомицетов Западно-Сибирской равнины]. UIF «Nauka», Ekaterinburg, 231 pp. [In Russian]. [ISBN 5-7691-0380-9]

- Mukhin VA, Tret'yakova AS, Pryadein DV, Paukov AG, Yudin MM, Fefelov KA, Shiryaev AG (2003) Plants and fungi of the National Park «Pripyshminskie bory» [Растения и грибы национального парка «Припышминские боры»]. Izdatel'stvo Ural'skogo Universiteta, Ekaterinburg, 204 pp. [In Russian]. [ISBN 5-86037-053-9]

- Murashkinskiy KE, Ziling MK (1928) Mycoflora of Altay and Sayany [Материалы по микофрлоре Алтая и Саян]. Trudy Sibirskogo Instituta Sel'skogo Khozyaystva i Lesovodstva 10 (4): 361-390. [In Russian].

- Nikitina SM (2008a) Pathogenic micromycetes and optimization of the phytosanitary state of onions in the forest-steppe of the Ob region [Патогенные микромицеты и оптимизация фитосанитарного состояния лука в лесостепи Приобья]. Novosibirskiy Gosudarstvennyy Agrarnyy Universitet, Kinel', 24 pp. [In Russian].

- Nikitina SM (2008b) Complex resistance of perennial onions to diseases [Комплексная устойчивость многолетних луков к заболеваниям]. Sibirskiy Vestnik Sel'skokhozyaystvennoy Nauki 10 (190): 38-41. [In Russian]. URL: https://elibrary.ru/ item.asp?id=11609234

- Nozdrenko MV (1960) Fungal phytopathogens of the city of Novosibirsk [Главнейшие грибные болезни зеленых насаждений Новосибирска]. Trudy Tsentral'no-Sibirskogo Botanicheskogo Sada 3: 57-64. [In Russian].

- Nozdrenko MV (1961) Plant diseases of the city of Novosibirsk [Болезни зеленых насаждений города Новосибирска]. Rastitel'nye bogatstva Novosibirskoy oblasti [Растительные богатства Новосибирской области]. Izd-vo SO AN SSSR, Novosibirsk, 189-197 pp. [In Russian].

- $\quad$ Nozdrenko MV (1964) Fungal phytopathogens of the city of Novosibirsk [Грибы зеленых насаждений городов Новосибирской области]. Vodorosli i Griby Sibiri i Dal'nego Vostoka 1 (8): 196-203. [In Russian]. 
- $\quad$ Nozdrenko MV (1965) Fungal phytopathogens of Pinus sibirica [Материалы к микофрлоре сибирского кедра]. Vodorosli i Griby Zapadnoy Sibiri 2: 142-148. [In Russian].

- $\quad$ Nozdrenko MV (1974) Species diversity of phytopathogens of parks in Novosibirsk Scientific Center [Основной состав грибов зеленых насаждений Академгородка (Новосибирск)]. Aquatic and terrestrial lower plants of Siberia [Водные и наземные сообщества низших растений Сибири]. Nauka, Novosibirsk, 136-147 pp.

[In Russian].

- Paukov A, Davydov E, Nordin A, Roux C, Şenkardeşler A, Sohrabi M, Vondrák J, Frolov I, Teptina A, Shiryaeva A (2019) Three new species, new combinations and a key to known species of Lobothallia (Megasporaceae). The Lichenologist 51 (4): 301-322. https://doi.org/10.1017/s0024282919000264

- Paukov AG, Davydov EA (2020) Aspicilia stalagmitica (Megasporaceae) - a new lichen species with isidia-like thalline outgrowths [Aspicilia stalagmitica (Megasporaceae) новый вид лишайника с изидиевидными выростами таллома]. Turczaninowia 23 (1): 5-12. https://doi.org/10.14258/turczaninowia.23.1.1

- Perova NV, Gorbunova IA (2001) Macrofungi of the Southern West Siberia [Макромицеты юга Западной Сибири]. Izd-vo SO RAN, Novosibirsk, 158 pp. [In Russian]. [ISBN 5-7692-0460-5]

- $\quad$ Perova NV, Gorbunova IA (2007) Mushrooms [Грибы]. In: Lashchinskiy NN (Ed.) Flora of Salair [Флора Салаирского кряжа]. Geo, Novosibirsk, 70-97 pp. [In Russian]. [ISBN 978-5-9747-0093-4].

- Protsenko MA, Makarevich EV, Ibragimova ZB, Filippova El, Vlasenko VA, Mazurkova NA (2019) Antiviral activity of Bjerkandera adusta extracts against influenza and herpes viruses [Противовирусная активность экстрактов макромицета Bjerkandera adusta в отношении вирусов гриппа и герпеса]. Biofarmatsevticheskiy Zhurnal 11: 38-44. [In Russian]. URL: https://elibrary.ru/item.asp?id=41865731

- Rebriev YA, Gorbunova IA (2007) Gasteromycetes of the Southwestern and Central Siberia [Гастеромицеты юга Западной и Средней Сибири. Sibirskiy Botanicheskiy Vestnik 2 (1): 51-60. [In Russian].

- $\quad$ Savich VY, Elenkin AA (1950) Introduction to the flora of lichens of the Asian part of USSR [Введение к флоре лишайников Азиатской части CCCP]. Trudy Botanicheskogo Instituta Imeni V.L. Komarova AN SSSR 2 (6): 181-343. [In Russian].

- Sedel'nikova NV, Romanova EV (2010) Lichens as bioindicators of atmospheric pollution of the Novosibirsk urban agglomeration. [Лишайники - биоиндикаторы атмосферного загрязнения Новосибирской городской агломераци]. Akademicheskoe izd-vo «Geo», Novosibirsk, 99 pp. [In Russian]. [ISBN 978-5-904682-04-0]

- Sedel'nikova NV (2017) Species diversity of lichens of Western Siberia and role of lichens in the mountain and plain phytocenoses. [Видовое разнообразие лихенобиоты Западной Сибири и оценка участия видов лишайников в основных её горных и равнинных фитоценозах]. Akademicheskoe izd-vo «Geo», Novosibirsk, 61 pp. [In Russian]. [ISBN 978-5-9909583-5-7]

- Shirjaeva OS (2015) Research history and species richness of agaricoid fungi in Sverdlovsk region [История изучения и видовое богатство агарикоидных базидиомицетов Свердловской области]. Vestnik Orenburgskogo Gosudarstvennogo Pedagogicheskogo Universiteta 4: 49-58. [In Russian]. 
- Shiryaev AG (2008a) Species diversity of macromycetes of Sverdlovsk region [Видовое разнообразие гастеромицетов Свердловской области]. Mycology and Phytopathology 42: 330-341. [In Russian]. URL: https://www.elibrary.ru/item.asp? id=11646312

- Shiryaev AG (2008b) Basidiomycetes of anthropogenic territories of the Urals [Клавариоидные грибы антропогенных территорий Урала]. Vestnik Ekologii, Lesovedeniya i Landshaftovedeniya 8: 80-91. [In Russian].

- Shiryaev AG, Gorbunova IA (2012) The destribution specificy of the zonal clavarioid mycocomplexes in the south-eastern part of West Siberia [Особенности распределения зональных комплексов клавариоидных грибов юго-восточной части Западной Сибири. Rastitel'nyy Mir Aziatskoy Rossii 2 (10): 1-10. [In Russian]. URL: http://www.izdatgeo.ru/pdf/rast/2012-2/3.pdf

- $\quad$ Singer R (1943) Das System der Agaricales. III. Annales Mycologici, 41. Verlag von "NATURA", Berlin, 189 pp. [In German].

- Skachko EY (2003) Lichens of the steppe and forest-steppe zones of the Altai region and their use for bioindication. [Лишайники степной и лесостепной зон Алтайского края и их использование для биоиндикации состояния окружающей среды]. Altayskiy Gosudarstvennyy Agrarnyy Universitet, Barnaul, 20 pp. [In Russian]. URL: https://elibrary.ru/item.asp?id=19301185

- Sokolovskaya TV, Golovina MR (1973) Powdery mildew in the Siberian Botanical Garden [Мучнистая роса в Сибирском ботаническом саду]. Zashchita rasteniy 6: 49. [In Russian].

- Sorokina NV (2001a) Analysis of lichen flora of the central and southern forest-steppe zone of the Omsk region [Анализ лихенофлоры центральной и южной лесостепи Омской области]. Sibirskiy Ekologicheskiy Zhurnal 8 (4): 501-506. [In Russian].

- Sorokina NV (2001b) Lichens of the southern forest-steppe zone of the Omsk region [Лишайники южной лесостепи Омской области]. Novosti Sistematiki Nizshikh Rastenii 34: 185-188. [In Russian].

- Stepanova NT, Sirko AV (1977) Additions to flora of Agaricoid fungi and Gasteromyetes in the Urals [К фолоре агариковых грибов и гастеромицетов Урала]. In: Stepanova NT, Demidova ZA (Eds) Mycological research in the Urals [Микологические исследования на Урале]. Ural Branch ASUSSR, Sverdlovsk, 51-106 pp. [In Russian].

- Tomoshevich M, Kirichenko N, Holmes K, Kenis M (2013) Foliar fungal pathogens of European woody plants in Siberia: an early warning of potential threats? Forest Pathology 43 (5): 345-359. https://doi.org/10.1111/efp.12036

- Tomoshevich MA, Vorob'eva IG (2005) Powdery mildew of Siberian species of Salix L. [Мучнистая роса сибирских видов рода Salix L.]. Sibirskiy Ekologicheskii Zhurnal 12 (4): 771-775. [In Russian].

- Tomoshevich MA, Vorob'eva IG (2010) Pathogenic micromycetes of woody introduced species of the Rosaceae family. Arboretum collection of the Central Siberian Botanical Garden. [Патогенные микромицеты древесных интродуцентов семейства Rosaceae. Коллекция арборетума Центрального сибирского ботанического сада.]. Akademicheskoe izd-vo «GEO», Novosibirsk, 116 pp. [In Russian]. [ISBN 9785904682026]

- Tomoshevich MA, Banaev EV (2011) Conjugate analysis of arboriflora and pathogenic mycobiota of Novosibirsk [Сопряженный анализ арборифлоры и патогенной 
микобиоты г. Новосибирска]. Vestnik IrGSKhA 44 (1): 144-152. [In Russian]. URL: https://elibrary.ru/item.asp?id=16551580

- Tomoshevich MA (2012) Atlas of pathogenic micromycetes of wooden plants of Siberia. [Атлас патогенных микромицетов древесных растений Сибири]. Akademicheskoe izd-vo «GEO», Novosibirsk, 250 pp. [In Russian]. [ISBN 978-5-904682-81-1]

- Tomoshevich MA, Banaev EV (2013) Concerning regularities in the structure of pathogenic micromycetes on leaves of woody plants in urban ecosystems of Siberia. Contemporary Problems of Ecology 6 (4): 396-401. https://doi.org/10.1134/ s1995425513040124

- Tomoshevich MA, Banaev EV (2017) Coupled analysis of arboriflora and pathogenic mycobiota in the city of Barnaul [Сопряженный анализ арборифлоры и патогенной микобиоты г. Барнаула.]. Vestnik Altayskogo Gosudarstvennogo Agrarnogo Universiteta 3 (149): 93-99. [In Russian].

- Tomoshevich MA (2020) Interrelations between alien and native foliar fungal pathogens and woody plants in Siberia. Contemporary Problems of Ecology 12 (6): 642-657. https://doi.org/10.1134/s1995425519060143

- Tomoshevich MA, Vorob'eva IG (2020) Interrelations between Syginga plants and phytopathogens in Siberia [Взаимоотношения растений рода Syringa и фитопатогенов в условиях Сибири]. Izvestiya Vysshikh Uchebnykh Zavedeniy. Povolzhskiy Region, Estestvennye Nauki 4 (32): 54-66. [In Russian]. https://doi.org/ 10.21685/2307-9150-2020-4-6

- Toropova EY, Kazakova OA, Vorob'eva IG, Selyuk MP (2013) Fusarium root rot of grain crops in Western Siberia and the Trans-Urals [Фузариозные корневые гнили зерновых культур в Западной Сибири и Зауралье]. Zashchita i Karantin Rasteniy 9: 23-26. [In Russian]. URL: http://www.z-i-k-r.ru/ZiKR_2013/ZiKR_09_2013.pdf

- Toropova EY, Vorob'eva IG, Mustafina MA, Selyuk MP (2019) Monitoring of Fusarium Link and its mycotoxins on wheat grain in Western Siberia [Мониторинг грибов рода Fusarium Link. и их микотоксинов на зерне пшеницы в Западной Сибири]. Agrokhimiya 5: 76-82. [In Russian].

- Toropova EY, Vorob'ova IG, Kirichenko AA, Trunov RI (2021) Parasitic activity of plant pathogens at the underground organs of spring wheat in the West Siberia. Journal of Physics: Conference Series 1942: 012079. [In English]. https://doi.org/10.1088/ 1742-6596/1942/1/012079

- Transhel' VG (1939) Overview of rust fungi of the USSR [Обзор ржавчинных грибов CCCP]. Izd-vo AN SSSR, M.-L., 426 pp. [In Russian].

- Troshkova GP, Kostina NE, Protsenko MA, Skarnovich MA, Mazurkova NA, Ibragimova ZB, Makarevich EV, Filippova El, Shishkina LN, Vlasenko VA (2013) Fruiting bodies of fungi as sources of biologically active substances with antiviral activity [Плодовые тела высших грибов - источники биологически активных веществ с противовирусной активностью]. Mezhdunarodnyy Zhurnal Eksperimental'nogo Obrazovaniya 7: 124-125. [In Russian]. URL: https://elibrary.ru/item.asp?id=20218580

- Vasil'evskiy NN, Karakulin BP (1937) Parasitic imperfect fungi. I. Hyphomycetes [Паразитные несовершенные грибы. І. Гифомицеты]. Izd-vo AN SSSR, M.-L., 517 pp. [In Russian].

- Vasil'evskiy NN, Karakulin BP (1950) Parasitic imperfect fungi. II. Melanconiales [Паразитные несовершенные грибы. II. Меланкониальные]. Izd-vo AN SSSR, M.-L., 680 pp. [In Russian]. 
- Vlasenko AV (2008) History of the study of myxomycetes in Western Siberia [История изучения миксомицетов на территории Западной Сибири]. Sovremennaya Mikologiya v Rossii. Tezisy Dokladov 2-go S'ezda Mikologov Rossii 2: 56-57. [In Russian].

- Vlasenko AV (2011) Myxomycetes of the Tigirek State Nature Reserve (annotated species list) [Миксомицеты Тигирекского заповедника (аннотированный список видов)]. Trudy Tigirekskogo Zapovednika 4: 54-56. [In Russian]. URL: https://elibrary.ru/ item.asp?id $=18353788$

- Vlasenko AV, Novozhilov YK (2011) Myxomycetes in the pine forests on the right-bank part of the upper $\mathrm{Ob}$ river basin [Миксомицеты сосновых лесов правобережной части Верхнего Приобья]. Mycology and Phytopathology 45 (6): 465-477. [In Russian]. URL: https://elibrary.ru/item.asp?id=17105727

- Vlasenko AV (2013) Species diversity and taxonomic structure of slime molds in the intrazonal and zonal habitats in the Southern West Siberia [Видовое разнообразие и таксономическая структура миксомицетов зональных и интразональных биотопов равнинной территории юга Западной Сибири]. Rastitel'nyy Mir Aziatskoy Rossii 2 (12): 3-11. [In Russian]. URL: https://elibrary.ru/item.asp?id=20602216

- Vlasenko AV, Vlasenko VA (2015) Biodiversity of slime molds and aphyllophoroid fungi in protected areas of the Novosibirsk region «Berdskie skaly» and "Kamenistaya step' u sela Novososedovo» [Биоразнообразие грибообразных протистов и афиллофороидных грибов в памятниках природы регионального значения Новосибирской области «Бердские скалы» и «Каменистая степь у села Новососедово»]. Trudy Tigirekskogo Zapovednika 7: 199-200. [In Russian].

- Vlasenko AV (2020) Epiphytic myxomycetes on the bark of Salix and Populus in the south-east of Western Siberia [Эпифитные миксомицеты на коре Salix и Populus на юго-востоке Западной Сибири]. Samarskiy Nauchnyy Vestnik 9: 34-38. [In Russian]. https://doi.org/10.17816/snv202094104

- Vlasenko VA (2010) Polypores (Polyporaceae s.l.) of the pine woods in forest-steppe zone at the right bank of Ob river [Трутовые грибы (Polyporaceae s. І.) сосновых лесов лесостепной зоны правобережья Оби]. Mycology and Phytopathology 44 (1): 3-9. [In Russian]. URL: https://www.binran.ru/files/journals/MiF/2010 44/MiF 2010 44 1_Vlasenko.pdf

- Vlasenko VA (2013a) Aphyllophoroid fungi of pine forests on the right bank of the Upper Ob basin. [Афиллофороидные грибы сосновых лесов правобережья Верхнего Приобья]. Akademicheskoe izdatel'stvo «Geo», Novosibirsk, 105 pp. [In Russian]. [ISBN 978-5-906284-31-0]

- Vlasenko VA (2013b) Aphyllophoroid fungi [Афиллофороидные грибы]. In: Zhimulev IF (Ed.) Dynamics of Ecosystems of the Novosibirsk Academgorodok [Динамика Экосистем Новосибирского Академгородка]. Izdatel'stvo SO RAN, Novosibirsk, 438 pp. [In Russian]. [ISBN 978-5-7692-1261].

- Vlasenko VA (2014) Aphyllophoroid fungi [Афиллофороидные грибы]. In: Vlasenko VA (Ed.) Plant diversity of the Central Siberian Botanical Garden [Растительное Многообразие Центрального Сибирского Ботанического Сада]. Akademicheskoe izdatel'stvo «GEO», Novosibirsk, 492 pp. [In Russian]. [ISBN 978-5-906284-51-8].

- Vlasenko VA, Vlasenko AV (2017a) Aphyllophoroid fungi of the protected area «Berdskie skaly» (Novosibirsk region) in the foothills of the Salair ridge [Афиллофороидные грибы памятника природы «Бердские скалы» 
(Новосибирская область) в предгорных районах Салаирского кряжа]. Nauchnye Vedomosti Belgorodskogo Gosudarstvennogo Universiteta. Seriya: Estestvennye Nauki 41 (25): 70-78. [In Russian]. URL: http://nv.bsu.edu.ru/nv/mag/detail.php?ID=448752

- Vlasenko VA, Vlasenko AV (2017b) Rare clavarioid fungi of the forest-steppe zone in the south-east of the Western Siberia [Редкие клавариоидные грибы лесостепной зоны юго-востока Западной Сибири]. Nauchnaya Zhizn' 11: 128-133. [In Russian]. URL: https://elibrary.ru/item.asp?id=32574888

- Vlasenko VA, Turmunkh D, Dondov B, Nanagyulyan SG, Mustafaev IM (2019) New records of aphyllophoroid fungi for the Baikal-Lensky Nature Reserve (Irkutsk Region) [Новые для Байкало-Ленского заповедника (Иркутская область) находки афиллофороидных грибов]. Izvestiya Irkutskogo Gosudarstvennogo Universiteta. Seriya «Biologiya. Ekologiya» 28: 91-100. [In Russian]. https://doi.org/10.26516/ 2073-3372.2019.28.91

- Vondrák J, Frolov I, Davydov EA, Urbanavichene I, Chesnokov S, Zhdanov I, Muchnik E, Konoreva L, Himelbrant D, Tchabanenko S (2016) The extensive geographical range of several species of Teloschistaceae: evidence from Russia. The Lichenologist 48 (3): 171-189. https://doi.org/10.1017/s0024282916000116

- Vondrák J, Frolov I, Davydov EA, Yakovchenko L, Malíček J, Svoboda S, Kubásek J (2019) The lichen family Teloschistaceae in the Altai-Sayan region (Central Asia). Phytotaxa 396 (1): 166. https://doi.org/10.11646/phytotaxa.396.1.1

- Vorob'eva IG, Chulkina VA, Gorbunov AB, Tomoshevich MA (2011) Ecological niches of pathogenic micromycetes of berry plants of the Vacciniaceae family [Экологические ниши патогенных микромицетов ягодных кустарничков подсемейства Vaccinioideae]. Sibirskiy Ekologicheskii Zhurnal 18 (3): 341-348. [In Russian]. URL: https://www.sibran.ru/upload/iblock/369/36925cf9c0ce5b05a5b0515b152a4b09.pdf

- Vorob'eva IG, Tomoshevich MA (2017) Phytopathogens of leaves of woody plants in the urban area of Kemerovo and Krasnoyarsk [Фитопатогены листьев древесных растений в урбанизированной среде Кемерово и Красноярска]. Vestnik Irgsha 79: 93-102. [In Russian]. URL: https://elibrary.ru/item.asp?id=29028324

- Vorob'eva IG, Tomoshevich MA, Elisafenko TV (2018) Mycobiota of plant leaves of the genus Viola (Violaceae) from the collection of the Central Siberian Botanical Garden SB RAS [Микобиота листьев растений рода Viola (Violaceae) в коллекции центрального Сибирского ботанического сада СО РАН]. Rastitel'nyy Mir Aziatskoy Rossii 4 (32): 3-10. [In Russian]. URL: https://elibrary.ru/item.asp?id=36648220

- Vorob'eva IG, Tomoshevich MA (2021) Leaf diseases of Betula L. species in the Siberian region [Болезни листьев видов рода Betula L. в Сибирском регионе. Byulleten' Glavnogo Botanicheskogo Sada 2: 62-72. [In Russian]. https://doi.org/ 10.25791/BBGRAN.02.2021.1093

- Yakovchenko LS, Vondrák J, Ohmura Y, Korchikov ES, Vondrákova OS, Davydov EA (2017) Candelariella blastidiata sp. nov. (Ascomycota, Candelariaceae) from Eurasia and North America, and a key for grey thalli Candelariella. The Lichenologist 49 (2): 117-126. https://doi.org/10.1017/s0024282917000020

- Yakovchenko LS, Davydov EA (2018) Sporastatia crassulata, a new species from the Altai Mountains with a key to Sporastatia and remarks on some additional species. The Lichenologist 50 (4): 439-450. https://doi.org/10.1017/s0024282918000282

- Yakovchenko LS, Davydov EA, Ohmura Y, Printzen C (2019) The phylogenetic position of species of Lecanora s. I. containing calycin and usnic acid, with the description of 
Lecanora solaris Yakovchenko \& Davydov sp. nov. The Lichenologist 51 (2): 147-156. https://doi.org/10.1017/s0024282919000045

- $\quad$ Zhukov AM (1978) Fungal phytopathogens of the forests of the Upper Ob [Грибные болезни лесов Верхнего Приобья]. Nauka, Novosibirsk, 246 pp. [In Russian].

- Zhukov AM (1979) Pathogenic fungi of sea buckthorn cenoses in Siberia. [Патогенные грибы облепиховых ценозов Сибири]. Nauka, Novosibirsk, 240 pp. [In Russian].

- Zhukov AM (1980) Lignicolous fungi of Priobye [Дереворазрушающие грибы Приобья]. Algae, fungi and lichens of the Southern Siberia [Водоросли, грибы и лишайники юга Сибири]. Nauka, Moscow, 144-183 pp. [In Russian].

- Zhukov EA (2002) Peculiarities of diffusion and existence of wood-destroying fungi of the order Aphyllophorales (Basidiomycetes) in nature [Особенности распространения и существования дереворазрушающих грибов порядка Aphyllophorales (Basidiomycetes) в природе]. Sibirskij Ekologicheskij Zhurnal 2: 2013-2020. [In Russian].

- Zhukov EA (2005) Aphyllophoroid fungi of low-mountain dark-coniferous formations of Western Siberia. [Афиллофороидные грибы низкогорных темнохвойных формаций Западной Сибири]. Vserossiyskiy Nauchno-issledovatel'skiy Institut Lesovodstva i Mekhanizatsii Lesnogo Khozyaystva, Moskva, 192 pp. [In Russian].

URL: https://elibrary.ru/item.asp?id=16062370

\section{Supplementary material}

\section{Suppl. material 1: The bibliography of mycological research in southern West Siberia} doi

Authors: Nina Filippova, Dmitry Ageev, Sergey Bolshakov, Evgeny A. Davydov, Aleksandra Filippova, llya Filippov, Sergei Gashkov, Irina Gorbunova, Ludmila Kalinina, Nadezhda Kudashova, Ekaterina Palomozhnykh, Natalia Shabanova, Maria Tomoshevich, Olga Vayshlya, Anastasia Vlasenko, Vyacheslav Vlasenko, Irina Vorob'eva, Lidia Yakovchenko, Elena Zvyagina Data type: Bibliography

Brief description: The bibliography presents all mycological scientific publications (journal papers, conference proceedings, $\mathrm{PhD}$ theses, monographs and book chapters) related to the mycological research in southern West Siberia from the beginning of research to date.

Download file $(269.74 \mathrm{~kb})$ 